\title{
Students' Perceptions on the Use of Project-Based Learning in CLIL: Learning Outputs and Psycho-Affective Considerations
}

Percepciones de los estudiantes sobre el uso del aprendizaje basado en proyectos en AICLE: resultados del aprendizaje y consideraciones psicoafectivas

Percepções dos alunos sobre o uso da aprendizagem baseada em projetos em CLIL: resultados de aprendizagem e considerações psicoafetivas

Rosa Sánchez-García

https://orcid.org/oooo-oooI-69I I-4688

Universidad de Loyola, Spain rsanchez@uloyola.es

Víctor Pavón-Vázquez https://orcid.org/0000-0003-3063-1746

Universidad de Córdoba, Spain victor.pavon@uco.es

Received: 14/09/2020

Accepted by peers: 19/05/2021
Sent to peer review: $15 / 01 / 2021$

Approved: 04/06/2021

DOI: 10.5294/laclil.2021.14.1.3

To reference this article (APA) / Para citar este artículo (APA) / Para citar este artigo (APA)

Sánchez-García, R. \& Pavón-Vázquez, V. (2021). Students' perceptions on the use of Project-Based Learning in CLIL: Learning outputs and psycho affective considerations. Latin American Journal of Content \& Language Integrated Learning, 14(1), 69-98. https://doi. org/10.5294/laclil.2021.14.1.3 
ABSTRACT. The Content and Language Integrated Learning (CLIL) approach has become one of the most frequent teaching options used as a pivotal element of bilingual programs. Over the last two decades, a lot has been written about its characteristics, its potential, and the methodological approaches that should be used to encourage such programs. Since the main objective of CLIL is to improve the use of the foreign language as a vehicle for communication by students when accessing and manipulating content matter, it seems evident that methodological strategies should be promoted to provide the opportunity to maximize the use of the language within the classroom. In this respect, project-based learning (PBL) is depicted, in principle, as an ideal proposal for CLIL, since its implementation will entail an increase in language management. Especially concerning the content, this will result in an improvement in students' ability to perform more comfortably in school and, presumably, more effectively. Nevertheless, there might not be such a straightforward cause-effect relationship and, therefore, it is necessary to dig deeper into the real impact of using PBL. This study is aimed at analyzing its influence from the students' point of view, to drill down on their feelings and behavior towards PBL and how they tackle and solve the arising challenges. Results have shown interesting information about their views on the benefits of working by projects but also some concerns regarding the use of this teaching and learning model.

Keywords (Source: Unesco Thesaurus): project-based learning; content and language integrated learning learning outcomes; psycho-affective factors; students' collaboration.

RESUMEN. El enfoque denominado aprendizaje integrado de lengua y contenido (AICLE) se ha convertido en uno de los enfoques utilizados más frecuentemente como elemento central de los llamados programas bilingües. En las dos últimas décadas se ha escrito abundantemente sobre sus características, su potencial y sobre cuáles deben ser las líneas metodológicas que deben animar a este tipo de programas. Dado que el objetivo principal es mejorar el uso de la lengua extranjera utilizada como vehículo de comunicación por parte del alumnado, parece obvio que se deben fomentar estrategias metodológicas que proporcionen la oportunidad de maximizar el uso de la lengua dentro del aula. En este sentido, el aprendizaje basado en proyectos (ABP) se presenta, en principio, como una propuesta ideal para AICLE, puesto que su aplicación va a suponer un aumento en el manejo de la lengua. Especialmente en lo que concierne al aprendizaje de los contenidos, ello redundará en una mejora en la capacidad del alumnado para desenvolverse académicamente de forma más cómoda y, presumiblemente, más efectiva. Sin embargo, esta relación causa-efecto puede no ser tan directa y, por ello, es necesario indagar sobre cuál es el impacto real del uso del ABP. En este estudio pretendemos analizar esta influencia desde el punto de vista del alumnado, con el objeto de analizar sus emociones y comportamiento y cómo se enfrentan y resuelven los retos que se presentan. Los resultados muestran información interesante acerca de sus opiniones con respecto al trabajo por proyectos, pero también han aflorado algunas preocupaciones relacionadas con el uso de este modelo de enseñanza y aprendizaje.

Palabras clave (Fuente: tesauro de la Unesco): aprendizaje basado en proyectos; aprendizaje integrado de contenido y lengua; resultados de aprendizaje; factores psico-afectivos; colaboración.

RESUMO. A abordagem denominada aprendizagem integrada de linguagem e conteúdos (CLIL) tornou-se uma das mais utilizadas como elemento central dos chamados programas bilingues. Nas últimas duas décadas, muito foi escrito sobre suas características, suas potencialidades e quais deveriam ser as linhas metodológicas que deveriam incentivar esse tipo de programas. Dado que o objetivo principal é melhorar a utilização da língua estrangeira utilizada como veículo de comunicação pelos alunos, parece óbvio que devem ser promovidas estratégias metodológicas que proporcionem a oportunidade de maximizar a utilização da língua na sala de aula. Neste sentido, a aprendizagem baseada em projetos (PBL) apresenta-se, em princípio, como uma proposta ideal para CLIL, uma vez que a sua aplicação significará um aumento do uso da língua. Especialmente no que diz respeito à aprendizagem de conteúdo, isso resultará em uma melhoria na capacidade dos alunos de funcionar academicamente de forma mais confortável e, presumivelmente, de forma mais eficaz. No entanto, essa relação de causa-efeito pode não ser tão direta e, portanto, é necessário indagar sobre o real impacto do uso da PBL. Neste estudo pretendemos analisar esta influência do ponto de vista dos alunos, de forma a analisar as suas emoções e comportamentos e como enfrentam e resolvem os desafios que surgem. Os resultados mostram informações interessantes sobre as suas opiniões sobre o trabalho do projeto, mas também surgiram algumas preocupações relacionadas com a utilização deste modelo de ensino e aprendizagem.

Palavras-chave (Fonte: tesauro da Unesco): aprendizagem baseada em projetos; aprendizagem integrada de conteúdo e linguagem; resultados de aprendizagem; fatores psicoafetivos; colaboração. 


\section{Introduction}

In recent decades, a new inclusive approach to the use of language has been witnessed with the emergence of the so-called Content and Language Integrated Learning, CLIL, (Coyle et al., 2010), which has positioned itself as a catalyst for language development within the curriculum (Eurydice, 2006). This instructional proposal has its theoretical and empirical basis in Content-Based Instruction programs (CBI) (Marsh \& Langé 1999; Marsh \& Marshland, 1999; Met, 1998), defined by Krahnke (1987) as "the teaching of content or information in the language being learned with little or no direct or explicit effort to teach the language itself separately from the content being taught” (p. 65). Specifically, in CLIL, teaching of content goes hand in hand with the teaching of language, as CLIL has a dual-focused objective that "advocates the learning of academic content and a foreign language simultaneously" (Coyle et al., 2010, p. 6).

CLIL implies a change of perspective in language and content learning (Mehisto et al., 2008). Its success is due not only to the quality of teaching within the classroom, but also to organizational decisions simultaneously made within the school. One of the noteworthy elements of this approach is that it is an active student-centered methodology (Grenfell, 2002), as opposed to the way that knowledge is transmitted in traditional methodologies. CLIL objectives explicitly include promoting and motivating student participation, taking into account their different characteristics. In CLIL, learning is something that the learner must make happen through the use and handling of information, giving them an active role in the learning process (Mehisto et al., 2008).

Given that student's interaction has a major value in CLIL, it seems logical to think that other proposals that also promote participation, interaction, and collaboration among students can be of great help in the development of this approach. These include Project-Based Learning (PBL), in which the promotion of interaction stands out as one of its central elements. Also, a growing number of teachers admit the need to seek new methodological proposals that align the teaching and learning process with the new $21^{\text {st }}$ Century demands (Pérez-Gómez, 
2007; Vergara, 2015). Educators remark the suitability of PBL, not only to develop deeper content understanding through the stimulation of participation and interaction, but also to foster students' acquisition of the skills and competences they will need for their academic, professional, and personal future (Larmer et al., 2015). Due to its specific characteristics, it seems that PBL may become a very useful pedagogical model for CLIL, considering that it is the content that vertebrates language learning and the foreign language the instrument that conveys the acquisition of such content (Mehisto et al., 2008).

Following this, it is supposed that, when implementing PBL in bilingual education within a CLIL framework, both proposals can merge in a synergy that contributes to improving the teaching and learning process. Research has normally focused on the influence of PBL on the learning of a foreign language in EFL and in content-based instruction (Allan \& Stoller, 2005; Beckett, 2005; Beckett \& Slater, 2005; Beckett \& Slater, 2018; Stoller, 1997, 2006; Stoller \& Myers, 2020; Terrazas-Arellanes et al., 2015), but not so much specifically in CLIL (Sierra, 2011; Lagasabaster \& López 2015). As Casan-Pitarch (2015) points out, the number of students analyzing the impact of PBL on students in CLIL contexts is scarce. Moreover, collecting qualitative data regarding their opinions and feelings is still an area somehow unexplored. In this study, we will deal with the basic principles of both CLIL and PBL, looking for the identification of the conditions that students perceive when operating them in parallel, and we will try to evince the most relevant benefits and potential problems of working with PBL in CLIL.

\section{Literature Review}

\section{Characteristics of PBL}

Project-Based Learning is a proposal that does not obey a strict mainstream, since this method comes from different sources and its structure has suffered different transformations (Pozuelos, 2007). Notwithstanding the difficulties in providing an exact definition of PBL, "it is easier to define what PBL is not [...], it is more difficult to define 
what it is" (Hallermann et al., 2011, p. 5); PBL can be summarized as "learning through the process of producing and completing a Project" (Gras-Velázquez, 2020, p. 1). It seems clear, though, that we are faced with a method that puts into practice a type of learning centered on students (Ribé, 2000; Vergara, 2015), having the improvement of their competences and skills as one of its paramount axes: "an extended, student-influenced inquiry process structured around complex, authentic questions and carefully designed products and learning tasks" (Hallermann et al., 2011, p. 5).

PBL puts forward an innovative pedagogy based on collaboration and cooperation among students and meets all the requirements to be considered a worthwhile instructional method (Stoller, 2006, p. 24). However, PBL is not, as has been considered, a breakthrough (Larmer et al., 2015; Pozuelos, 2007), as its origins are associated to Dewey's constructivist "learning by doing". Nevertheless, as pointed out by Howell (2003), Knoll (1997), and Larmer et al., (2015), project work had already been documented in the $16^{\text {th }}$ Century with the so-called progetti (projects) of the Italian school of architecture, it was later widely used in artistic and technical studies in Paris, and, as early as the $18^{\text {th }}$ Century, began to be used in engineering studies in North America and Europe. Nowadays, PBL is clearly associated to fostering inquiry-based learning experiences, problem-solving, collaborative projects and, in general, to proposals marked by a profound constructivist and participative nature (Cuban, 2001; Harris, 2001; Heinecke et al., 1999; Lenz et al., 2015; Ringstaff \& Kelley, 2002).

Project-based learning falls within the group of active methodologies whose evolution has been analyzed by Marqués (2001) to identify the process of change experienced by education, through four fundamental didactic models: expository, instructive, active student, and collaborative. The collaborative model goes one step further by creating a basic curriculum in a new paradigm of teaching called "open learning" (Dewey, 1933), which inherits the rationales of the active school, under the assumption that "the active side precedes the passive in the development of the child-nature" (Dewey, 1897, p. 13), focusing on the role of the teacher as a mediator of learning. 


\section{PBL in CLIL}

As we have seen, many of the theoretical principles underlying PBL are very similar to those advocated in CLIL. The conversion of lectures into participatory ones, the promotion of collaboration and cooperation proposals. Using PBL obviously has an impact on the development of the linguistic proficiency of the students, primarily because "it creates purposeful opportunities for language input, language output and explicit attention to language-related features" (Stoller, 2006, p. 32). This is perhaps one of the aspects that most supports the use of PBL in bilingual programmes, and particularly in CLIL, as meaning construction greatly depends on the language use when acquiring content matter: "the ability to understand curricular content and attain curricular goals rest to a considerable degree on being able to handle language" (Dalton-Puffer, 2013, p. 218).

Furthermore, one of the reasons for using PBL is that this model, like the CLIL approach, involves a change in classroom dynamics: "...takes students outside of the traditional classroom environment and into a vibrant, experimental one" (Gras-Velázquez, 2020, p. 1). PBL proposes a type of active methodology based on two fundamental teaching models: active learner and collaborative learning (Marqués, 2001), as similarly advocated in CLIL. Indeed, the use of active methodologies such as scaffolding (both content and language), group work, task-based learning, cooperative and collaborative learning, and continuous formative assessment (Pavón, 2017), is intrinsic to PBL. This type of methodology allows students to leave behind a passive role, since they are provided with learning environments rich in educational resources in which they can develop projects and activities that allow them to discover, develop and apply knowledge (Stoller \& Myers, 2020). This is, as we can see, a way of considering teaching and learning that is completely in line with CLIL principles.

Similarly, the emphasis on encouraging cooperation and collaboration between students through group work is also one of the common pillars for CLIL: "A lot of what goes on in the CLIL classroom involves practical application of knowledge through problem solving tasks and 
cooperative learning" (Pavón \& Ellison, 2013, p. 73); and for PBL: "projects should be developed through cooperative working, giving students the opportunity to decide in groups the best options for each project so as to obtain successful solutions and outcomes" (Casan-Pitarch, 2015, p. 225). The main objective of collaboration in both proposals is the use of knowledge in real situations in which what has been learned can be transferred to unknown and new settings (Larmer \& Mergendoller, 2015). The collaborative work inherent in PBL and CLIL in the completion of tasks and projects develops this connectivity and makes learning a relevant and sustainable element resulting from the experience of cultural exchange (Vergara, 2015).

Another synergy between CLIL and PBL is an increased learner motivation. Working cooperatively creates a safe learning environment, as the possibility of sharing ideas increases individual strengths, self-esteem, and, therefore, interest in learning (Stoller, 2006). Motivation results from active participation in tasks or projects with an appropriate level of difficulty "characterised by the right amount of challenge" (Stoller, 2006, p. 29). This issue will be dealt specifically in the following section on the role of psycho-affective factors.

\section{Psycho-affective factors in CLIL and PBL}

Recent neuroscience studies have shed much light on the relationships between emotions and learning (Blakemore \& Frith, 2011; Davidson \& Begley, 2012; Rilling et al., 2002). This interconnectivity demonstrates that a learner's emotional engagement with what they are studying is fundamental to their learning; otherwise, their brain will not cooperate with the task (Pease \& Hahn, 2015). Therefore, "for optimal learning to occur, students need to be emotionally competent" (Blakemore \& Fith, 2011, p. 304), which includes the ability to restrain oneself and restrain impulsive reactions to external stimuli, favouring more conscious cognitive processes, such as planning and decision-making.

When focusing on the psycho-affective dimension of learning, PBL offers the ideal framework to escape from the adhesive learning typical of traditional methods (Meltzer \& Harris, 1990). First, it places emotion at the center of learning, which consequently increases motivation and self-esteem (Stoller, 2006). Second, as it promotes an 
increase of autonomy, independence, initiative, and responsibility (Stoller \& Myers, 2020). This leads us to conclude that both PBL and CLIL are postulated as proposals that favor meaningful learning that emanates to a large extent from motivation, which is considered to be the central axis that links the learner emotionally with the content (Chambers, 1999; Dörnyei, 2001). This may be largely due to the intrinsic characteristics of CLIL as "a sound pedagogy through which learners can use language as a medium to learn language form, content, and sociocultural knowledge" (Slater \& Beckett, 2019, p. 2).

In general, research on the implementation of PBL brings to light conclusions that are in line with the above-mentioned principles. Thus, many authors consider that PBL maximizes student motivation (Blumenfeld et al., 1991; Brophy, 2013; Larmer, 2015; Larmer et al., 2015; Stoller, 2006; Thomas, 2000; Vergara, 2015). In line with this, Cáceres and Unigarro (2007) designed a project integrating content and language in primary education to teach the solar system aimed at eliciting oral, written and artistic production. They followed Fried-Booth (1990) in several steps: stimulus, definition of the objective, practice of language skills, design of written materials, group activities, collecting information, organization of material, and final presentation. They found a noticeable positive reaction from the students in terms of a high degree of interest, interaction and participation, and increased motivation, but, above all, with respect to the quality of their production in the three areas. Also, Sierra (2011) tested the development of projects based on music by students over the course of a whole year, after which they were asked about their feelings and performance during the process. Perhaps the most noticeable discovery was that the students showed a high degree of motivation with respect to using PBL, especially when analysing how they perceived the way they interacted and cooperated.

However, these results have not been fully corroborated in other studies and some experts doubt whether to consider motivation as a result of the learner's involvement in the project, or, on the contrary, there may be a prior intrinsic motivation in the learner that leads him/ her to participate in them. Thus, Lasagabaster and López (2015) conducted a study in primary education comparing the use of a methodology based on books with the use of PBL in two contexts, CLIL and EFL, 
with the objective of delving into the relationship between these variables and students' motivation. Results showed that the impact of PBL was not significant for extrinsic and instrumental motivation and with regards to the interest in other cultures and could only be perceived for intrinsic and integrative motivation. They concluded that project work does not in itself increase positive attitudes and motivation in students: "teachers should work on how to design projects that will motivate students more, as merely implementing PW is not a panacea" (p. 55). However, they also pointed out that, probably, the fact that subject matter was not based on curriculum contents and the connection with real life really determined whether or not students were interested in this type of learning.

\section{Research method}

\section{Objectives}

The general purpose of this study is to analyze the students' perceptions about the impact of using Project-Based Learning (PBL) in a Content and Language Integrated Learning (CLIL) context. More precisely, the following specific objectives have been set:

1. To investigate how students perceive the impact of PBL on language and content learning.

2. To evaluate the influence of PBL on the psycho-affective dimension, especially concerning the increase of students' interest and motivation.

3. To analyze the effect of PBL on students' interaction and collaboration.

4. To identify the challenges in the use of PBL and the possible negative aspects that may arise.

\section{Context and participants}

This is a qualitative descriptive study in which researchers have limited to collecting the necessary information in order to describe the 
application of a certain pedagogical model to a given student population group with homogeneous characteristics. A qualitative model has been chosen to provide a more personal and free view of students' opinions: "the process involves analysing transcripts, identifying themes within those data and gathering together examples of those themes from the text." (Burnard et al., 2008, p. 429).

The study was carried out in a primary and secondary school in Seville (Spain). It is a private school, located in a middle-class community. A total of 45 students participated in two different years $-5^{\text {th }}$ year of primary education and $4^{\text {th }}$ year of compulsory secondary education.

In the $5^{\text {th }}$ year of primary education, $50 \%$ of the students were female and 50\% male, aged between 10 (55\%) and 11 (45\%), being mostly Spanish (86\%) but also British (9\%) and Chinese (5\%). In this class, $95 \%$ of the students had been studying CLIL for more than 6 to 10 years and $5 \%$ for 1 to 5 years, with A1 being the most frequent level of English (91\%), followed by A2 (9\%). The subjects taught in English were Natural and Social Sciences, Arts, Physical Education, and Music.

In the $4^{\text {th }}$ year of compulsory secondary education, $38 \%$ of the students were female and $62 \%$ were male, with ages ranging from $14(4 \%)$, 15 (67\%) and 16 (29\%), being mostly Spanish (84\%), but also Portuguese (4\%), French (4\%), German (4\%) and American (4\%). In this class, $67 \%$ of the students had been studying CLIL for more than 10 years, $21 \%$ for 6-10 years, and $12 \%$ for $1-5$ years, with B2 being the most frequent level of English (67\%), followed by B1 (13\%), C1 (8\%), A2 (8\%), and C2 (4\%). The subjects taught in English were Natural and Social Sciences, Arts, and Physical Education.

\section{Intervention: characteristics of the project}

The main goal of the project was to study the dangers of an inappropriate use of mobile phones while driving. They had to work collaboratively to investigate the concepts and interrelations between speed, displacement, and time, in order to estimate the impact of distractions caused by the use of mobile phones while driving. The project was scheduled for the second term of the academic year, during which the students had to complete a blueprint provided by the researcher. Under the teacher observation and supervision, the students had to 
gather experiential data, create tables, graphs, and results to obtain conclusions applied to real life. The final product was a video shoot in which they stated the question, showed the results of their investigation, and drew conclusions. They finally presented their videos to the rest of the class and shared them with the police authorities in charge of traffic control (Directorate General of Traffic).

The main resources used to accomplish the project were on-site facilities (labs and classroom materials), ICT devices (laptops, mobile phones, stopwatches, IWB), and human resources (experts on the topic). Both formative assessment (through observation, draft deliveries, and tasks presentations) and summative assessment (teacher, peer- and self-evaluation with rubrics) were deployed. Notably, besides the achievement of a certain result, one of the main demeanors of organization of the students' project is the use of a foreign language at all implementation stages. Consequently, they implemented and presented their results through receptive and productive communicative attainment. As for the specific competences in use, the students had to do some critical thinking in order to solve a problem; they had to organize, analyze and synthesize information to develop well-reasoned conclusions, and also judge the relevance of some information against relevant criteria. When doing the presentation, they had to organize ideas and develop content appropriate to the situation, while using effective oral presentation skills.

\section{Research tools}

The data was collected during the third quarter of the 2019-2020 academic year. Prior to gathering the data, the researchers conducted two semi-structured interviews with the teachers involved in the project with the purpose of providing them with a detailed description of the objectives of the study. Later on, there were two onsite visits to the classrooms during the implementation of the project in the second term in order to monitor the project's development. These visits were scheduled to create an atmosphere of trust and confidence that might help the students be more relaxed when answering the questions.

At the end of the project, the students were provided with a questionnaire with a first part aimed at obtaining personal and academic 
information. A second part was also administered with questions specifically related to the perceptions they had, mainly with respect to how much English and content they had learnt, use of their autonomy, creativity, degree of motivation and interest, interaction and collaboration with others, interaction with the teachers, and self-confidence. a space aimed at collecting information of a qualitative nature where they could express their opinions and feelings. The findings of this study have been taken from the comments of this complementary open section, so the qualitative analysis is conveyed through the written opinions of the students. We are well aware of the difficulties in capturing how PBL may affect students' performance and psycho-affective behavior; this is why we have opted to gather their opinions and views from a more reflective, judgmental, and even emotional point of view. Students' written responses were originally in Spanish and were later translated into English. We did so because we did not want a possible low level in the foreign language to compromise the richness of their responses.

Regarding data analysis, we have followed a grounded theory approach (Mackey \& Gass, 2005) in the idea that the inductive collection of emergent themes and subthemes was more appropriate for our purposes than establishing rigid categories.

\section{Results and Discussion}

Data obtained from the students' opinions are detailed below. Quotes have been used to demonstrate how the findings and the interpretations have arisen from the data. As stated above, the dimensions analyzed correspond to the objectives set in this study (impact of PBL on the students' learning of language and content, students' interest and motivation, collaboration, and possible negative aspects) and thematic subdivisions have been established in each of them in view of the specificity of the comments made by the students (see Table 1). The quotes have been chosen and labelled according to this code categorization. All the quotes have been identified with a code (T1, T2, etc.) and will 
be displayed in four different tables (Tables 2, 3, 4, and 5) between the presentation and the discussion of the results in every one of the four dimensions.

Table 1. Final coding framework, and emergent themes and sub-themes

\begin{tabular}{|c|c|c|}
\hline Coding framework & Emergent themes & Emergent sub-themes \\
\hline $\begin{array}{l}\text { 1. Impact of PBL on } \\
\text { learning }\end{array}$ & $\begin{array}{l}\text { - Language } \\
\text { - Content } \\
\text { - Competences }\end{array}$ & $\begin{array}{l}\text { - Improvement } \\
\text { - Understand better, real life } \\
\text { - Autonomy, critical thinking, } \\
\text { creativity, practicality }\end{array}$ \\
\hline $\begin{array}{l}\text { 2. Psycho-affective } \\
\text { aspects }\end{array}$ & $\begin{array}{l}\text { - Interest } \\
\text { - Fun model }\end{array}$ & $\begin{array}{l}\text { - Interesting work, more } \\
\text { motivating, effective } \\
\text { methodology } \\
\text { - Playful, enjoyable, } \\
\text { attractive learning }\end{array}$ \\
\hline $\begin{array}{l}\text { 3. Interaction and } \\
\text { collaboration }\end{array}$ & $\begin{array}{l}\text { - Collaboration and } \\
\text { teamwork } \\
\text { - Relationship } \\
\text { improvement }\end{array}$ & $\begin{array}{l}\text { - Participation, groupwork, } \\
\text { group identity, helping } \\
\text { weaker students } \\
\text { - Stronger internal ties, } \\
\text { communication, respect }\end{array}$ \\
\hline $\begin{array}{l}\text { 4. Challenges and } \\
\text { possible weaknesses }\end{array}$ & $\begin{array}{l}\text { - Distraction } \\
\text { - Lack of commitment } \\
\text { - Disagreements } \\
\text { - Quality decrease }\end{array}$ & $\begin{array}{l}\text { - Preference of individual } \\
\text { work, difficulty of group } \\
\text { management } \\
\text { - No engagement, possible } \\
\text { dependency } \\
\text { - Conflicts, lack of trust, lack } \\
\text { of acceptance } \\
\text { - Lack of depth, absence of } \\
\text { guidance, high effort }\end{array}$ \\
\hline
\end{tabular}

Source: Own elaboration.

\section{Impact of PBL on learning}

It can be unequivocally stated that students clearly express general satisfaction with the use of PBL and, more specifically, with the influence they perceive as existing between this type of teaching and the improvement of their learning. This positive assessment does not only concern language learning and academic content, but also extends to the awareness that they have acquired an array of specific skills and competences by using PBL. 


\section{Language}

More specifically, students express a clear improvement in the use of the foreign language (quote 1), as well as their ability to communicate in a group and acquire the specific vocabulary related to the contents (quote 2).

\section{Content}

As regards content learning, students also report a direct relationship between their deep understanding of academic content and the use of the PBL (quote 3). This type of improvement is mainly attributed to the need to search for information themselves (quote 4), but also to the fact of being helped by other students (quote 5). It is also worth noting the relationship they perceive between project-based teaching and the connection it helps them establish with the outside world and reality (quote 6).

\section{Competences}

Furthermore, when asked what type of competences they believe they have acquired, students highlight the achievement of a varied series of skills activated by the use of the $\mathrm{PB}$. They include those of social and communicative nature, together with those related to critical thinking and respect for others (quotes 7 and 8). Students also emphasize the practical aspect of the learning received, when appreciating its usefulness (quote 9), as well as the benefits that this type of work has had on their work-planning process (quote 10). They also mention some more specific skills related to digital competence (quote 11), although they particularly highlight the awakening of skills and ways of working related to their ability to search for information relevant to their subjects (quote 12). This also involves an increase in their creativity, autonomy, and independence to achieve a more enriching grasp (quote 13). To the direct question about the skills that they believe benefit most from working on projects, the answers are unanimous in affirming that the most developed skills are those related to the search for information, reflection, and teamwork (quote 14). 
Quote 1: "I have definitely improved my knowledge of English" (T32)

Quote 2: "It has helped me to improve my group communication and to acquire more scientific vocabulary of the subject matter of the project" (T8)

Quote 3: "I definitely acquire the content more deeply and understand it better" (T16)

Quote 4: "Because it makes me look for information and understand it" (T37)

Quote 5: "Since the doubts that arise are answered by my teammates and I

usually find out about the subject more quickly" ((T43)

Quote 6: "I think it prepares me for real life, because the knowledge I learn is put into practice" (T13)

Quote 7: "Autonomy in study, social competence, communication and cooperation, critical thinking" (T22)

Quote 8: "Social competence, listening skills, critical thinking, group

leadership, respect for opinions" (T27)

Quote 9: "From my point of view, this project was interesting and really useful to develop skills" (T1)

Quote 10: "Working in groups, getting organized, planning for the long term" (T29)

Quote 11: "Editing and creating videos and audio-visual communication skills" (T39)

Quote 12: "You need to investigate and help the group, so you develop new skills such as research" (T31)

Quote 13: "It helps you to investigate, be creative, more independent, work with more people, etc." (14)

Quote 14: "Teamwork, information and research" (T24)

Source: Own elaboration.

The first aspect that should be highlighted is that their opinions mostly convey the idea that they consider PBL a highly positive model because it has a clear impact on learning outcomes. Thus, they state that working through projects has led to an improvement in the use of the additional language - in this case, English — and that they feel more comfortable and able to use it while learning the academic content. There is no doubt that this is due to the fact that the possibilities of interaction multiply when having to work in a group and that the increased need to handle English to understand others and to make themselves understood has increased their communication skills.

In addition to the improvement in the use of English, the students also mainly coincide in pointing out that PBL has definitely contributed to improving the learning of academic content. They consider that the 
effort to learn these contents is smaller when carrying out a project, that they learn faster, and that the contents are better assimilated. As we will also see later, it seems clear that, according to their statements, the acquisition of knowledge and the way in which learning occurs are directly related to the search for information, group work, and collaboration. The possibility of exchanging information and helping each other turns out to be decisive for them to perceive that their capacity for learning improves and that the results are more optimal working in this way.

Regarding the competences that they believe they have acquired or improved, their opinions are again unanimous in stating that working on projects has meant that they improve their communication skills, their social competence, respect for others, their capacity for reflection, and, above all, their abilities to seek information and investigate. According to their opinions, PBL must be considered as a catalyst of competences, making the emergence and development of capacities and abilities that the students may not have been aware of and whose presence clearly affects an increase in the quality of learning.

\section{Psycho-affective aspects}

Another concept many students noted in their answers is related to the psycho-affective dimension of learning, more specifically to the increase of interest in learning by using projects and the increase of motivation that the use of this type of learning has brought to them. For instance, the emphasis of students on pointing out the enjoyable aspect of learning by projects is also remarkable; identifying how pleasurable learning in this way provides a distinctive and outstanding element of learning by projects, which is ultimately a prerequisite to enhance students' interest and motivation in class.

\section{Interest and motivation}

In general, the students' responses are geared to rating project work as a more interesting way of teaching, as this makes the content more attractive (quote 15). The fact that learners perceive learning as more interesting has a clear-cut effect on increasing their motivation. To the question of why they find project work more interesting, they frequently answer affirmatively (quote 16), and students clearly establish a 
cause-effect relationship between the increase of motivation and their improved learning quality (quote 17). As for the reasons identified by the students to justify that they are more motivated by working on projects, their answers suggest that this is due to the different dynamics established in the classes, on the one hand, and to the use of a greater asset of materials and resources, on the other (quotes 19 and 19). Finally, this increased motivation and interest in learning through projects is echoed in their desire to implement this model to other subjects (quote 20).

\section{Fun model}

The fun dimension associated with project learning is perhaps the most common element pointed out by students as characteristic of this type of learning. Appraisals such as "dynamic," "entertaining," and "fun" are repeated very frequently in their answers, which, in the eyes of the students, makes the ludic characteristics of project learning one of its most significant elements (quote 21). This view on the part of students that working on projects is more fun and enjoyable is not simply a matter of supporting this relationship, but rather students clearly indicate that this type of instructional model results in an improvement in the quality of learning (quote 22). In short, students consider this type of learning more attractive, motivating, and effective, opinions that are reflected jointly and synthetically in this last quotation (quote 23).

\section{Table 3. Psycho-affective aspects}

Quote 15: "Projects offer more interesting ways of learning about topics" (T35) Quote 16: "There is a motivation that inspires a student when it comes to a project with interesting ideas" (T11)

Quote 17: "A group project motivates more than an individual project and by motivating students, it makes us learn better" (T18)

Quote 18: "Learning is more active, classes are more fun and we are more motivated at school"

Quote 19: "We use a variety of different materials in each class" (T37)

Quote 20: "I would like to see more subjects taught in English" (T8)

Quote 21: "It's a more fun way to learn" (T24)

Quote 22. "As it is a fun experience, you remember the content better, which is positive" (T42)

Quote 23: Learning is more active, you learn more and better, classes are more fun and we are more motivated at school" (T2)

Source: Own elaboration. 
When analyzing the comments related to the psycho-affective dimension and the emotional state of the students, two main issues arise. First, their views are unequivocal in pointing out that the type of learning proposed by project work is more attractive. Thus, the content, the classes, and the learning, in general, are disclosed as more interesting, which automatically causes the students to be attracted to this kind of work and, ultimately, makes them much more motivated. The increase in motivation is reflected in the fact that students come to ask that this way of working be extended and that the number of subjects involved in carrying out projects be expanded. It is clear, therefore, that PBL influences the promotion of a more positive attitude towards learning on the part of the students and, above all, a significant increase in their motivation.

Second, if we analyze their comments regarding the reasons why they find learning more interesting and are more motivated to do so, most students have a very clear idea of why. For them, it is a more active, dynamic and, above all, more fun way of working. However, the emphasis on pointing out that it is much more fun to learn does not exclude the certainty that, in addition, learning this way is not only more fun, but it also improves their results. The reasons, to our knowledge, seem clear. PBL proposes a more autonomous way of working, in the sense that there is a departure from the figure of the teacher as the only guide in the acquisition of knowledge and, thus, the learning model shifts completely from unidirectional to participatory and collaborative, setting a scenario in which students are endowed with the power and ability to decide what type of information is relevant. This combination of autonomy and independence from the teacher and collaborative work with classmates seems to be the key to considering PBL as a more motivating and effective way of learning.

\section{Interaction and collaboration}

One of the most attractive aspects of PBL is the fact that its working proposal is essentially based on the promotion of teamwork, which implies a learning model that encourages collaboration and reciprocal support. This, in turn, leads to greater interaction and participation by group members, thus clearly aligning with one of CLIL's most important 
assumptions. As we will see in light of their opinions, two aspects are particularly highlighted by learners: the establishment of a very strong collaborative and teamwork framework, which has beneficial effects on learning, and the clear influence that working on projects has on improving group cohesion.

\section{Collaboration and teamwork}

The most straightforward conclusion we find after analyzing the students' opinions is their assumption that PBL not only provides them with an opportunity to collaborate through teamwork, but also encourages their participation (quote 24). When talking about collaboration, the students express themselves in the same way as with the psycho-affective dimension, highlighting the playful aspect of learning by establishing a direct connection between learning and teamwork, and the improvement of knowledge and group member relationships (quote 25). More particularly, regarding the results of collaboration, they also establish a connection between this way of working and the clear impact it has on improving learning (quote 26).

Their views also emphasize that their increased capacity to understand and retain concepts and ideas is mainly due to the exceptional nature of PBL to establish an exchange of information experiences, which ultimately ends up favoring the learning of the weakest students in the group (quote 27). In addition, students remark that working on projects not only improves interaction, communication, and collaboration between group members, but, similarly, it increases interaction and communication with their teachers (quote 28).

\section{Relationship improvement}

Undoubtedly, one of the students' most frequent comments in relation to the influence of PBL on their way of working is linked to the relationships established between the members of the group. Students particularly refer to the beneficial effects that project work has on their collaboration and on how a working relationship is established within the group (quote 29). This improvement is ostensibly based on the knowledge that each group member offers by working collaboratively (quote 30). 
In light of their comments, students clearly believe that working on projects helps bring the group together, as it demands a close and permanent interaction and collaboration among the members of the group (quote 31). Students thus conclude, in addition to the above, that the achievement of results is closely related to the establishment of a partnership based on respect and communication (quote 32).

Table 4. Interaction and collaboration

Quote 24: "You learn to work as a team" (T16)

Quote 25: "“It improves empathy, enquiry and collaboration" (T40)

Quote 26: "It becomes more enjoyable and we all help each other to learn

the contents effectively" (T27)

Quote 27: "You can collaborate with your colleagues, covering the weaknesses of each one" (T13)

Quote 28: "I talk more with my colleagues since it is vital for the good development of the project. And it makes me communicate more with the teacher to transmit my doubts" (T19)

Quote 29: "The relationship with colleagues improves a lot" (T3)

Quote 30: "It can bring us closer together, as teamwork allows you to get to know people better" (T43)

Quote 31: "The relationship with everyone becomes more personal and closer" (T35)

Quote 32: "It improves the relationship because you have to live with them and respect each other, otherwise the work will not be easy and effective" (T9)

Source: Own elaboration.

The dynamics established among the group members becomes the third relevant aspect in the analysis of the students' opinions. Increasing collaboration and helping each other become two of the most positive elements being talked about in their reviews. Students positively value the fact that working on projects has meant learning to work in a group, collaborating with their classmates, and appreciating their contributions. In their opinion, the exchange of information that takes place between them and the help they give each other are essential to achieve results. The students also state that working on projects ensures that the less strong students can keep up with the work rhythm and do not lag behind. Furthermore, PBL is more enjoyable and manages to improve empathy and communication, not only among group members but also with teachers. As we can see, the exchange 
of information becomes the central element. The need to interact promotes greater participation, which in turn makes students know each other better and feel more comfortable.

In this sense, the students also emphasize the fact that joint and collaborative work makes the relationship between them improve significantly. There is a greater mutual knowledge, which in turn strengthens the union and cohesion among the members of the group. In this way, students also learn to respect the opinions of others and establish a greater relationship of closeness. Again, it is necessary to refer to the interaction between group members, the increased communication that causes the exchange of information, and the need to collaborate, as the keys that explain the improvement that occurs in coexistence within the group. It seems obvious to point out that the emotional relationships established in the group become a fundamental aspect in PBL and constitute the cornerstone on which much of its effectiveness is based.

\section{Challenges and possible weaknesses}

As we have seen through the students' comments, in their opinion, PBL represents a very positive working model that generates a series of clear benefits in terms of learning outcomes, clearly influences positively the way students work, and is directly related to an improvement in the affective side. However, some students also warn that working with projects can have several undesirable effects. Although these comments do not correspond to most of their views, they should be taken into account when organizing and planning any project. Some learners specifically pointed out that, since teamwork is the central element of PBL, it can sometimes be distracting for some of its members, there can be a lack of involvement and disagreement between group members, and, accordingly, it can be detrimental to the achievement of learning outcomes.

\section{Distraction}

Although it was not a very recurrent comment, it is true that, among the less positive surveys, some students troublingly mention teamwork distraction. Thus, when asked if they have perceived any negative effects of working on projects, they have replied affirmatively and shared some negative consequences that PBL had on their learning 
(quote 33). In this respect, it seems clear that, for some students, working in groups is, in fact, a hindrance to their learning, and they prefer to work individually, in their belief that this way their learning is not slowed down or impaired (quote 34).

As for the reasons to consider why working in a group is a distraction and detrimental to the learning of some students, everything points clearly to the fact that the management of the group can sometimes be complicated (quote 35). However, there are also those who say that group work, even when distracting, is still a very positive experience and does not impair the speed or quality of their learning (quote 36).

\section{Lack of commitment}

One of the explanations typically expressed by students as to why PBL is sometimes not entirely successful and why it can lead to an unsuitable learning environment is due to the lack of commitment by other group members (quote 37). The possibility that some members of the group may not be thoroughly engaged is a matter of concern to many because of the possible negative implications this may have on their project's final assessment (quote 38). Moreover, students are also concerned that working in a group may cause some learners to become less engaged when they receive the constant support and help of other members of the group (quote 39).

\section{Disagreements}

Another less positive aspect often referred to by learners when asked about possible negative effects of PBL, though it barely happens, is the possibility that they may not fully agree (quote 40 ). We have also found complaints from some students that their contributions have sometimes not been given due attention, proven to be a millstone for them (quote 41). We consider it is crucial to shed light on possible gender disputes, as inferred from one comment by a girl when she complains about the boys being a source of problems and distraction during group work (quote 42).

\section{Quality decrease}

To conclude with our findings stemming from the less positive comments by the students regarding the use of PBL, we must acknowledge 
their awareness of potential problems and detrimental consequences that may arise when working through projects. Hence, either because of the way the contents are treated, the characteristics of the sources of information, the attention of the teachers, or the amount of time and effort that PBL implies, the students perceive that, in some cases, the quality of the learning may suffer.

More specifically, students are concerned about the lack of depth when dealing with the contents and demand greater attention to them (quote 43). Students sometimes complain about the problems of working with information that they have to look for themselves, either because the sources are unreliable or because the information is far too complex and difficult to understand properly without the right help (quote 44). Finally, the students' comments also refer to the amount of time and effort required to work on projects, particularly complaining about how much of their free time the project may take up, often being forced to work outside of school. Their overall feeling in this respect is that projects are so time-consuming that it can be detrimental to other subject content allocation (quote 45).

Table 5. Challenges and possible weaknesses

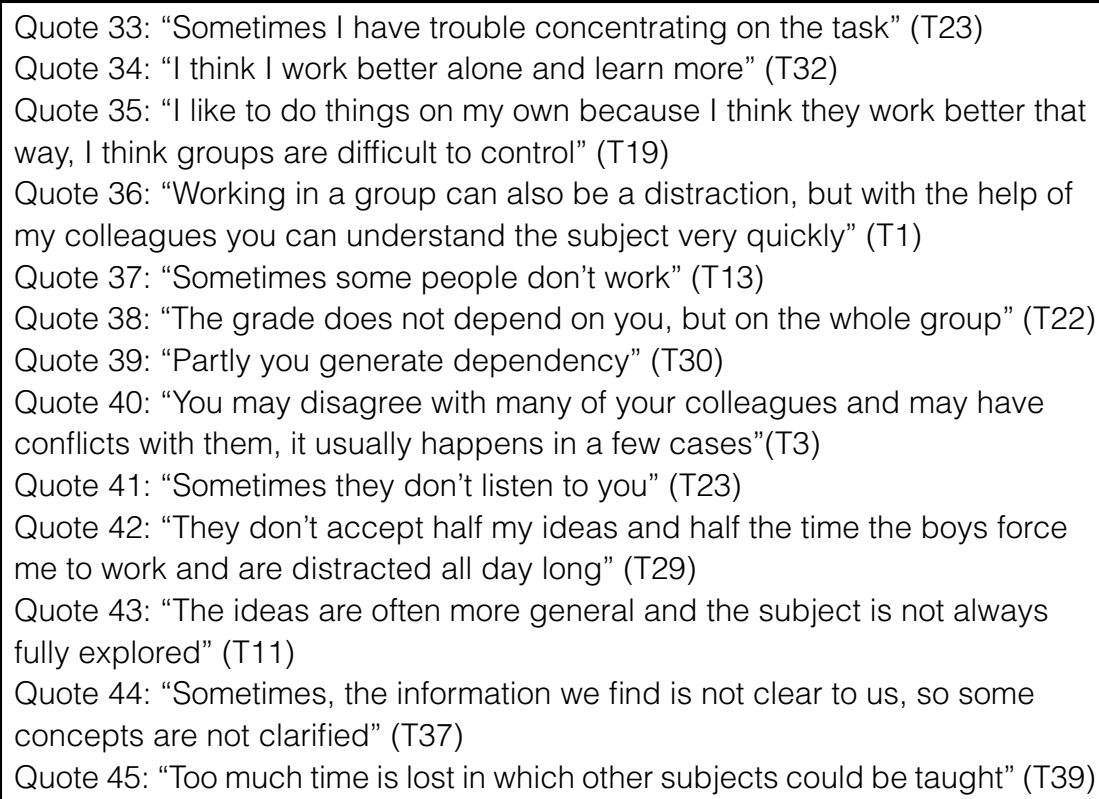

Source: Own elaboration. 
Finally, other significant aspects that we have found when analyzing the opinions and perceptions of students regarding PBL are not, however, entirely positive. Although it is true that most of their comments value very positively what it means to work on projects, it is also possible to find opinions that identify some of the potential challenges and problems that students may encounter working in this way. According to these comments, some students warn that, sometimes, a lack of concentration can occur because they get distracted while working in a group, which will consequently affect their learning. The difficulty that sometimes exists to control the group can cause these unwanted situations and makes them consider that they could learn faster and consolidate knowledge better if they worked individually. They also complain that there are students who may not show the proper involvement in the work in comparison with the rest of their colleagues and, due to this, they are concerned about the negative effect that acts for which they are not responsible may have on their grades. On the other hand, they also point out the possibility of disagreements between group members that could even lead to conflicts. In one of the comments, it is suggested that it is often the boys who cause the problems, as they generate most of the distraction and do not take into account the opinions of others; however, since it is only one opinion, we cannot assume with certainty that it is a situation that is repeated frequently and that we find ourselves with a possible gender problem. However, this type of behavior can be harmful and put work dynamics and results at risk, although the view of the students' opinions seems to be that they are not general problems but, rather, specific ones. It is possible that all these problems are caused by a lack of understanding of the basic principles of group work by the students, by a certain laxity in their control by the teachers, or by a combination of both. In any case, establishing more specific rules and exercising tighter control over work dynamics could solve this kind of dysfunctions, especially during the first stages, until a habit of behavior can be consolidated that helps to erase any possible problems of coexistence.

Perhaps the most worrying thing is that, in some cases, students realize that project work can compromise the quality of their learning. Thus, they complain that the contents are sometimes glossed over and without the necessary depth, and demand that more time be devoted to 
them so that the content can be properly assimilated. Sometimes, they also affirm that the information they obtain from the internet may not be of sufficient quality, or that, on the contrary, it is highly complex, so they require more help to understand it. But above all, the most repeated negative opinion focuses on the excessive effort required by project work. Specifically, they complain about the repercussions of the effort that is demanded since they must resort to using part of their free time to be able to complete the tasks assigned. These are problems that may all be caused by incorrect work planning, both in terms of the characteristics of the information provided and the workload assigned. In addition, this necessarily means that attention must be paid to the design of the project, to providing students with a guide to help them find the appropriate information regarding its origin and degree of complexity and, above all, to adapting the difficulty and the number of tasks to the students' characteristics and to the time they have in order not to overload their capacities. To avoid the possible appearance of these problems, it would be advisable for teachers to receive adequate training in the use of PBL, which means that training teachers appropriately to make students work on projects becomes a fundamental factor. In this way, it would be possible to optimize their capacities so that they could make the most of this educational proposal.

\section{Conclusion}

In this research, we tried to analyze the opinions of the students regarding the use of PBL in a CLIL teaching context. In particular, we aimed to investigate the students' perceptions on the impact of PBL on language and content learning, on their motivation, and on how work was carried out among them. In addition, we wanted to identify the challenges that this type of teaching brings about and its possible dark areas. Throughout the presentation of the opinions of the students, we were able to see that they have not limited themselves to expressing their views by sticking only to the aspects about which they were being asked. Through their comments, it was found that they have addressed a large number of aspects related to the main topics that 
have provided us with rich information about how learning itself occurs, but also about their feelings, emotions, and even concerns.

Although the opinions have been mostly positive and we can conclude that the use of PBL is beneficial for students' learning, including the emotional dimension, we also construe that attention must be paid to certain potentially problematic aspects to achieve that the benefits of working for projects translate into tangible results for students. We must also point out that it is evident that there is a concordance between PBL and CLIL and that working through projects has a positive effect on learning English and the contents; however, concerning the rest of the analyzed dimensions, the results of the research might have been similar if the context had not been CLIL.

Finally, we would like to allude to the limitations of this study, since, with a higher number of students, with more educational levels, and with more schools with different characteristics participating, the results would have been of higher quality. We hope that the results of this research will help to improve the understanding of the impact of PBL in CLIL and encourage us to extend our knowledge about its challenges and benefits in subsequent studies.

\section{References}

Alan, B., \& Stoller, F. L. (2005). Maximizing the benefits of project work in foreign language classrooms. English Teaching Forum, 43(4), 10-21.

Beckett, G. H. (2005). Academic language and literacy socialization through project-based instructions: ESL student perspectives and issues. Journal of Asia Pacific Communication, 15, 191-206. https://doi.org/10.1075/ japc.15.1.12bec

Beckett, G. H., \& Slater, T. (2005). The project framework: A tool for language, content, and skills integration. ELT journal, 59(2), 108-116. https://doi.org/10.1093/eltj/cci024

Beckett, G. H., \& Slater, T. (2018). Technology-integrated project-based language learning. In C. Chapelle (Ed.), The encyclopedia of applied linguistics (pp.1-8). Wiley-Blackwell. https://doi.org/10.1002/9781405198431. wbeal1487 
Blakemore, S. J., \& Frith, U. (2011). Cómo aprende el cerebro. Las claves para la educación. Booket.

Blumenfeld, P. C., Soloway, E., Marx, R. W., Krajcik, J. S., Guzdial, M., \& Palincsar, A. (1991). Motivating project-based learning: Sustaining the doing, supporting the learning. Educational Psychologist, 26(3-4), 369-398. https://doi.org/10.1207/s15326985ep2603\&4_8

Brophy, J. E. (2013). Motivating students to learn. Routledge. https://doi. org/10.4324/9780203858318

Burnard, P., Gill, P., Stewart, K., treasure, E., \& Chadwick, B. (2008). Analysing and presenting qualitative data. British Dental Journal, 204(8), 429-432. https://doi.org/10.1038/sj.bdj.2008.292

Cáceres, A., \& Unigarro, D. (2007). Analysis of children's English language learning evidences when engaging in project work. Profile, 8, 9-23.

Casan-Pitarch, R. (2015). Project work in CLIL: A bibliographical review. Latin American Journal of Content and Language Integrated Learning, 8(2), 212-236. https://doi.org/10.5294/laclil.2015.8.2.7

Chambers, G. N. (1999). Motivating language learners. Multilingual Matters.

Coyle, D., Hood, P., \& Marsh, D. (2010). CLIL content and language integrated learning. (Ed.). Cambridge University Press. https://doi.org/10.1017/ 9781009024549

Cuban, L. (2001). Oversold and underused: Computers in the classroom. Harvard University.

Dalton-Puffer, C. (2013). A construct of cognitive discourse functions for conceptualising content-language integration in CLIL and multilingual education. European Journal of Applied Linguistics, 1(2), 216-253. https://doi.org/10.1515/eujal-2013-0011

Davidson, R., \& Begley, S. (2012). El perfil emocional de tu cerebro. Destino.

Dörnyei, Z. (2001). Teaching and researching motivation. Longman. https://doi. org/10.1075/hop.5.mot1

Dewey, J. (1933). Cómo pensamos. Paidós.

Dewey, J. (1897). My pedagogic creed. Bibliolife.

Eurydice. (2006). Content and language learning (CLIL) at school in Europe. European Commission.

Fried-Booth, D. (1990). Project work. Resource books for teachers. Oxford University Press.

Gras-Velázquez, A. (2020). Project-based learning in second language acquisition: Building communities of practice in higher education. Routledge. https://doi.org/10.4324/9780429457432 
Grenfell, M. (Eds.). (2002). Modern languages across the curriculum. Routledge. Hallermann, S., Larmer, J., \& Mergendoller, J. (2011). PBL in the elementary grades: Step-by-step guidance, tools and tips for standards- focused K-5 projects. Buck Institute for Education.

Harris, J. (2001). Teachers as telecollaborative project designers: A curriculum-based approach. Contemporary Issues in Technology and Teachers Education, 1(3), 1-17.

Heinecke, W. F., Blasi, L., Milman, N., \& Washington, L. (1999). New directions in the evaluation of the effectiveness of educational technology. Presented at US Dpt. of Education secretary's conference on educational technology: Evaluating educational effectiveness. http://www.ed.gov/ rschstat/eval/tech/techconf99/whitepapers/paper8.html

Howell, R. T. (2003). The importance of the project method in technology education. Journal of Industrial Teacher Education, 4(3), 1-7.

Knoll, M. (1997). The project method: Its vocational education origin and international development. Journal of Industrial Teacher Education, 34(3), 59-80.

Krahnke, K. (1987). Approaches to syllabus design for foreign language teaching. Prentice Hall.

Larmer, J. (Ed.). (2015). Gold standard PBL: Project based teaching practices. Buck Institute for Education. http://bie.org/about/what_pbl

Larmer, J., Mergendoller, J. R., \& Boss, S. (2015). Setting the standard for project based learning: A proven approach to rigorous classroom instruction. ASCD.

Lasagabaster, D., \& López, R. (2015). The impact of type of approach (CLIL versus EFL) and methodology (book-based versus project work) on motivation. Porta Linguarum, 41-57. https://doi.org/10.30827/Digibug. 53737

Lenz, B., Wells, J., \& Kingston, S. (2015). Transforming schools. Using project-based learning, performance assessment, and common core standards. Jossey-Bass.

Mackey, A., \& Gass, S. M. (2005). Foreign language research. Methodology and design. Lawrence Erlbaum Associates.

Marqués, P. (2001). La enseñanza. Buenas prácticas. La motivación. http://tic. sepdf.gob.mx/micrositio/micrositio1/docs/materiales_estudio/u3_ 12/La_ensenanza_buenas_practicas_la_motivacion.pdf. 
Marsh, D., \& Langé, G. (eds.) (1999). Implementing content and language integrated language - A research-driven foundation course reader. TIE-CLIL: University of Jyväskylä.

Marsh, D., \& Marsland, B. (1999). Learning with languages. University of Jyväskylä.

Mehisto, P., Marsh, D., \& Frigols, M. J. (2008). Uncovering CLIL. Content and language integrated learning in bilingual and multilingual education. Macmillan Education.

Meltzer, D., \& Harris, M. (1990). Familia y comunidad. Spatia.

Met, M. (1998). Curriculum decision-making in content-based language teaching. In J. Cenoz \& F. Genesee (eds), Beyond bilingualism: Multilingualism and multilingual education (pp. 35-63). Multilingual Matters.

Pavón, V. (2017). Enfoque metodológico y enseñanza plurilingüe. Plan integral de excelencia educativa Oxford. Oxford University Press-España.

Pavón, V., \& Ellison, M. (2013). Examining teachers' roles and competences in Content and Language Integrated Learning (CLIL). Linguarum Arena, 4, 65-78.

Pease, J. B., \& Hahn, M. B. (2015). Detection of introgression in a five-taxon philogeny. Systematic Biology 64(4), 651-662.

Pérez-Gómez, A. I. (2007). La naturaleza de las competencias básicas y sus implicaciones pedagógicas. Cuadernos de educación: Cantabria.

Pozuelos, F. J. (2007). Trabajo por proyectos en el aula: descripción, investigación y experiencias. Ediciones MCEP. Cooperación Educativa.

Ribé, R. (2000). Introducing negotiation processes: An experiment with creative project work. In Breen, M. P. \& Littlejohn, A. (Eds). Classroom decision-making. Negotiation and process syllabuses in practice (pp. 63-82). Cambridge University Press.

Rilling, J., Gutman, D., Zeh, T., Pagnoni, G., Berns, G., \& Kilts, C. (2002). A neural basis for social cooperation. Neuron 35, 395-405.

Ringstaff, C., \& Kelley, L. (2002). The learning return on our educational technology investment. A review of findings from research. Wested RTEC, http:// www.wested.org/online_pubs/learning_return.pdf

Sierra, J. M. (2011). CLIL and project work: Contributions from the classroom: Content and language integrated learning. In Y. Ruiz de Zarobe, J. M. Sierra, \& Gallardo del Puerto, F. (Eds.), Contributions to multilingualism in European contexts (pp. 211-239). Lang. 
Slater, T., \& Beckett. G. (2019). Integrating language, content, technology, and skills development through project-based language learning: blending frameworks for successful unit planning. MEXTESOL Journal, 43(1), 1-14.

Stoller, F. (1997). Project work. A means to promote language content. English Teaching Forum, 35(4), 41-42.

Stoller, F. (2006). Establishing a theoretical foundation for project-based learning in second and foreign language contexts. In G. H. Beckett, \& P. C. Miller (Eds.), Project-based second and foreign language education: Past, present, and future (pp. 19-40). Information Age Publishing.

Stoller, F. L., \& Myers, C. C. (2020). Project-based learning. A five-stage framework to guide language teachers. In A. Gras-Velázquez (Eds.). Project-based learning in second language acquisition: Building communities of practice in higher education (pp. 25-47). Routledge. https://doi. org/10.4324/9780429457432-3

Terrazas-Arellanes, F. E., Knox, C., \& Walden, E. (2015). Pilot study on the feasibility and indicator effects of collaborative online projects on science learning for English learners. International Journal of Information and Communication Technology Education, 11(4), 31-50. https://doi. org/10.4018/IJICTE.2015100103

Thomas, J. W. (2000). A review of research on project-based learning. The Autodesk Foundation.

Vergara, J. J. (2015). Aprendo porque quiero. El aprendizaje basado en proyectos (ABP) paso a paso. SM. 